\title{
Encapsulation of Probiotics: Need of the Hour
}

\section{Amandeep Singh ${ }^{1,3 *}$, Rohit Bhatia ${ }^{2}$, Raj Kumar Narang ${ }^{2}$ and Uttam Kumar Mandal ${ }^{3}$}

${ }^{1}$ Department of Pharmaceutics, ISF College of Pharmacy, Moga, Punjab, India

${ }^{2}$ Department of Pharmaceutical Chemistry, ISF College of Pharmacy, Moga, Punjab, India

${ }^{3}$ Department of Pharmaceutical Sciences and Technology, Maharaja Ranjit Singh

Punjab Technical University, Bathinda, Punjab, India.

*Corresponding Author: Amandeep Singh, Assistant Professor, Departments of Pharmaceutics, ISF College of Pharmacy, Moga, Punjab, India.
Received: February 13, 2021

Published: March 29, 2021

(C) All rights are reserved by Amandeep

Singh., et al.
Over the past decades, the administration of probiotics has gained much attention. As per the definition of probiotics by WHO, these are living microorganisms used for the management of various diseases [1]. In the market various strains of probiotics are available. Depends on the properties of these probiotics stains they are used in the management of various diseases. Probiotic plays an imperative role in the prevention of ulcerative colitis. Probiotics guard the intestinal mucosal layer against the attack of microbes. Additionally, it also serves as immunoglobulins. Probiotics also having anti-oxidant and inflammatory properties. But it is evident that in the case of ulcerative colitis, the concentration of probiotics is reduced at the colonic site therefore probiotic formulations are given to the patients to manage the disease [2]. But the problems with the conventional probiotic formulation are their viability. The health benefits of probiotics are purely dependent on the viability and enough number of probiotics in the target intestine.

Maintaining the probiotic viability in the stomach is an additional difficult task for probiotics to reach the target site because most of the probiotics die or lose their functionality at acidic conditions $[1,3]$. Next, survived probiotics should be released at the target site of action which is usually the small or large intestine. Therefore, an ideal probiotic delivery system should protect probiotics from adverse conditions during fabrication and storage and in the acidic gastric environment so that a sufficient amount of probiotics is available in the site of action.
For the survival of probiotics during storage and transit through the digestive system, microencapsulation is necessary. Probiotics must be encapsulated because they are sensitive to conditions such as air, humidity, temperature, gastric $\mathrm{pH}$, or bile salt. Probiotic encapsulation technology is a stirring field of bio pharmacy that has emerged and developed rapidly from the past decade. Based on this technology, the availability of cells has been modulated by a large range of micro-organisms in semi-permeable and biocompatible materials [4].

In the most published literature interchangeable words immobilization, entanglement and encapsulation were used. Although encapsulation is the process of forming an internal matrix that is fully embedded within the capsule wall, immobilization refers to the trapping of material in or around a matrix. Encapsulation helps to regulate cell development, storage and handling, potentially improving cells' viability and stability [5]. An immobilized environment also provides additional protection during rehydration for probiotic cells. Controlled and continuing delivery of cells in the intestines is the strongest use of encapsulation in bio pharmacy [6]. Despite acidity in the stomach, the possible advantage of this therapeutic approach is retained cell viability. By utilizing the encapsulation techniques the efficiency of probiotics can be enhanced by protecting them from harsh acidic environments. 
Bibliography

1. A Singh., et al. "Probiotics and Herbals as a Boom in Treatment of Ulcerative Colitis". 14.2 (2020): 1-3.

2. S Ray. "Advanced colon-specific delivery systems for treating local disorders". Elsevier Ltd (2019).

3. LAAP Derikx., et al. "Probiotics and prebiotics in ulcerative colitis". Best Practice and Research: Clinical Gastroenterology 30.1 (2016): 55-71.

4. J Kim., et al. "Probiotic delivery systems: a brief overview". Journal of Pharmaceutical Investigation 46.4 (2016): 377-386.

5. SJ Eom., et al. "Increased antioxidative and nitric oxide scavenging activity of ginseng marc fermented by Pediococcus acidilactici KCCM11614P". Food Science and Biotechnology 27.1 (2018): 185-191.

6. Singh UK Mandal and RK Narang. "Development and characterization of enteric coated pectin pellets containing mesalamine and Saccharomyces boulardii for specific inflamed colon: In vitro and in vivo evaluation". Journal of Drug Delivery Science and Technology 60 (2021): 102393.

\section{Assets from publication with us}

- Prompt Acknowledgement after receiving the article

- Thorough Double blinded peer review

- Rapid Publication

- Issue of Publication Certificate

- High visibility of your Published work

Website: www.actascientific.com/

Submit Article: www.actascientific.com/submission.php

Email us: editor@actascientific.com

Contact us: +919182824667 